\title{
KONSEP “KHALÎFAH Fî AL-ARD” DALAM PERSPEKTIF ETIKA LINGKUNGAN
}

\author{
Dini Atikawatia*, Totok Gunawan ${ }^{\mathrm{b}}$, Sunarto $^{\mathrm{b}}$ \\ a Program Doktor Ilmu Lingkungan, Sekolah Pascasarjana, Universitas Gadjah Mada, \\ Jalan Teknika Utara, Pogung Kidul, Yogyakarta \\ ${ }^{b}$ Fakultas Geografi, Universitas Gadjah Mada, Sekip Utara, Jalan Kaliurang, Bulaksumur, Yogyakarta 55281 \\ *Email: dini_atikawati@yahoo.co.id \\ Diterima (received) 18 Januari 2019; disetujui (accepted) 29 Juli 2019; tersedia secara online (available online) 1 Agustus 2019
}

\begin{abstract}
Various environmental problems occur due to human behavior. This behavior is influenced by the way a person views his environment. The perspective is influenced by the values believed. Inappropriate behavior and low morale in managing the environment will cause damage. For this reason, a concept of human leadership is needed for nature which can be used as a guide for environmental management. This article aims to examine the concept of khaliffah fi al-ard in environmental ethics perspective. This article is the result of an in-depth study of relevant libraries. This article argues that the concept of khalîfah fì al-ard originating from the Qur'an is very relevant to environmental ethics biosentrism and ecocentrism. The concept of khaliffah fì al-ard which is interpreted as the representative of Allah on earth should be a human starting point in managing and maintaining the environment, so that this concept is one of the strategic means of structuring and maintaining the environment. The concept of khalîfah fì al-ard can be realized into a pro-environment movement. It is very important for us as Muslims to understand the essential meaning of ourselves as khalîfah fì al-ard who cares the earth from damage.
\end{abstract}

Keywords: earth; environment; ethics; khaliffah; perspective.

\begin{abstract}
Abstrak
Berbagai masalah lingkungan terjadi akibat perilaku manusia. Perilaku ini dipengaruhi oleh cara pandang seseorang terhadap lingkungannya. Cara pandang dipengaruhi oleh nilai-nilai yang diyakini kebenarannya oleh mereka. Perilaku yang kurang tepat dan rendahnya moral dalam pengelolaan lingkungan akan menyebabkan terjadinya kerusakan. Untuk itu, diperlukan adanya konsep kepemimpinan manusia terhadap alam yang dapat dijadikan pedoman untuk pengelolaan lingkungan. Artikel ini bertujuan untuk mengkaji konsep khalîfah fî al-ard dalam perspektif etika lingkungan. Artikel ini merupakan hasil pemikiran yang mendalam dari kajian pustaka-pustaka yang relevan. Artikel ini berpendapat bahwa konsep khalîfah fî al-ard yang bersumber dari al-Qur'an sangat relevan dengan etika lingkungan biosentrisme dan ekosentrisme. Konsep khaliffah fì al-ard yang dimaknai sebagai wakil Allah di muka bumi seharusnya menjadi titik awal manusia dalam mengelola dan memelihara lingkungan, sehingga konsep ini merupakan salah satu sarana strategis dalam penataan dan pemeliharaan lingkungan. Konsep khalîfah fì al-ard dapat diwujudkan menjadi suatu gerakan pro-lingkungan. Hal ini sangat penting bagi kita sebagai umat Islam untuk mengerti makna esensial diri kita sebagai khalîfah fí al-ard yang memelihara bumi dari kerusakan.
\end{abstract}

Kata Kunci: bumi; lingkungan; etika; khalîfah; perspektif.

\section{Pendahuluan}

Terjadinya berbagai kerusakan lingkungan diakibatkan oleh perilaku manusia. Perilaku ini dipengaruhi oleh cara pandang manusia terhadap lingkungannya. Cara pandang ini dipengaruhi oleh nilai-

doi: https://doi.org/10.24843/blje.2019.v19.i02.p05

(C) 2019 by the authors; Content from this work may be used under the terms of the Creative Commons Attribution 3.0 licence. Any further distribution of this work must maintain attribution to the author(s) and the title of the work, journal citation and DOI. Published under licence by Udayana University, Indonesia. 
nilai yang diyakini kebenarannya oleh mereka. Nilai-nilai ini sangat dipengaruhi etika lingkungan yang dijadikan sebagai pedoman hidupnya. Etika lingkungan sangat berpengaruh terhadap cara pikir dan cara tindak manusia dalam menanggapi lingkungan. Oleh karena itu, pemahaman, penghayatan, dan penerapan etika lingkungan yang tepat sangat penting untuk mendukung pengelolaan lingkungan (Tim MKU PLH, 2014).

Menurut Keraf (2010) munculnya masalah lingkungan adalah masalah moral dan persoalan perilaku manusia. Oleh karena itu, perlu etika dan moralitas untuk mengatasinya. Etika sebenarnya sudah melekat dalam diri seseorang sejak lahir. Tetapi akhir-akhir ini etika tidak muncul, walau kebijakan lingkungan sudah ada tetapi degradasi lingkungan juga semakin meningkat. Munculnya kerusakan ini karena etika lingkungan tidak pernah dikedepankan.

Etika mempelajari bagaimana seseorang merenungkan secara mendalam tentang berbagai ajaran moral (kebaikan). Etika lingkungan merupakan petunjuk atau arah perilaku praktis manusia dalam mengusahakan terwujudnya moral lingkungan. Konsep pengelolaan sumberdaya alam yang bertanggung jawab merupakan langkah baik dalam mengatasi kerusakan lingkungan. Pengelolaan sumberdaya alam yang bertanggung jawab merupakan proses pengelolaan sumberdaya alam yang sesuai dengan kebutuhan saat ini tanpa mengurangi kebutuhan generasi yang akan datang (Soemiarno dkk., 2010).

Dengan demikian, etika lingkungan tidak hanya mengimbangi hak dan kewajiban terhadap lingkungan, tetapi juga membatasi tingkah laku dan upaya untuk mengendalikan berbagai kegiatan agar tetap berada dalam batas kelentingan lingkungan. Dalam hal ini, etika lingkungan memberikan dampak positif untuk kesadaran moral, tanggung jawab, dan mengatur perilaku manusia terhadap lingkungan agar tidak mengeksploitasi sumberdaya alam secara berlebihan dan manusia merasa mempunyai peran aktif terhadap lingkungannya.

Dalam agama Islam, manusia mempunyai peranan penting dalam menjaga kelestarian lingkungan. Islam merupakan agama yang memandang lingkungan sebagai bagian tak terpisahkan dari keimanan seseorang terhadap Allah, manifestasi keimanan seseorang dapat dilihat dari perilakunya, sehingga dikenal adanya konsep kepemimpinan manusia terhadap alam, yaitu khalîfah fì al-ard yang disebutkan dalam ayat al-Qur'an. Hal ini dapat dijadikan sebagai pedoman dalam pengelolaan lingkungan.

Artikel ini bertujuan untuk mengkaji konsep khalîfah fî al-ard dalam perspektif etika lingkungan (antroposentrisme, biosentrisme, dan ekosentrisme). Artikel ini menggunakan metode studi kepustakaan, yaitu penelaahan terhadap buku-buku, literatur-literatur, catatan-catatan, dan laporan-laporan yang ada hubungannya dengan permasalahan yang dipikirkan (Nazir, 1988), sehingga diperoleh hasil kajian yang mendalam dari pustaka-pustaka yang relevan sebagai objek yang utama (Hadi, 1995). Pustaka-pustaka yang relevan yang digunakan dalam artikel ini meliputi al-Qur'an, buku-buku mengenai etika, lingkungan, etika lingkungan, dan konservasi alam dalam Islam serta peraturan perundang-undangan.

\section{Bahasan Utama}

\subsection{Pandangan-pandangan dalam Etika Lingkungan}

\subsubsection{Pandangan Antroposentrisme}

Antroposentrisme adalah teori etika lingkungan yang memandang manusia sebagai pusat alam semesta. Manusia dan kepentingannya dianggap yang paling menentukan dalam tatanan ekosistem dan dalam kebijakan yang diambil dalam kaitan dengan alam, baik secara langsung atau tidak langsung.

Nilai tertinggi adalah manusia dan kepentingannya. Hanya manusia yang mempunyai nilai dan mendapat perhatian. Segala sesuatu yang lain di alam semesta hanya akan mendapat nilai dan perhatian sejauh menunjang kepenting-an manusia. Oleh karenanya alam hanya dilihat sebagai obyek, alat dan sarana bagi pemenuhan kebutuhan dan kepentingan manusia. Alam hanya alat bagi pencapaian tujuan manusia. Alam tidak mempunyai nilai pada dirinya sendiri. 
Manusia dianggap berada di luar, di atas, dan terpisah dari alam. Bahkan manusia dipahami sebagai penguasa atas alam yang boleh melakukan apa saja. Cara pandang seperti itu melahirkan sikap dan perilaku eksploitatif tanpa kepedulian sama sekali terhadap alam dan segala isinya. Sebagai contoh, tradisi pembunuhan massal lumba-lumba di Faroe Island, Denmark yang merupakan tradisi tahunan masyarakat, eksploitasi emas Freeport Papua, dan penggundulan hutan di Jambi. Hal ini tentu saja menimbulkan berbagai dampak negatif dan merupakan perilaku yang tercela.

\subsubsection{Pandangan Biosentrisme}

Biosentrisme memiliki pandangan bahwa setiap kehidupan dan makhluk hidup mempunyai nilai dan berharga pada dirinya sendiri. Teori ini menganggap serius setiap kehidupan dan makhluk hidup di alam semesta. Semua makhluk hidup pantas mendapat pertimbangan dan kepedulian moral. Alam perlu diperlakukan secara moral, terlepas dari apakah ia bernilai bagi manusia atau tidak. Teori ini mendasarkan moralitas pada keluhuran kehidupan, entah pada manusia atau makhluk hidup lainnya.

Ada empat keyakinan biosentrisme. Pertama, manusia adalah anggota komunitas kehidupan di bumi dalam arti yang sama dan kerangka yang sama di mana makhluk hidup yang lain juga anggota dari komunitas yang sama. Kedua, bahwa spesies manusia, bersama dengan semua spesies lain adalah bagian dari sistem yang saling tergantung sedemikian rupa sehingga kehidupan ditentukan oleh relasi satu dengan lainnya. Ketiga, bahwa semua organisme adalah pusat kehidupan yang mempunyai tujuan sendiri. Keempat, bahwa manusia pada dirinya sendiri tidak lebih unggul dari makhluk hidup lainnya.

Pandangan biosentrisme membuat manusia menjadi lebih netral dalam memandang semua makhluk hidup dengan segala kepentingannya. Tentu saja manusia akan selalu memandang kepentingannya lebih penting. Dengan keyakinan tadi, manusia akan lebih terbuka untuk mempertimbangkan dan memperhatikan kepentingan makhluk hidup lainnya secara serius, khususnya ketika ada benturan kepentingan antara manusia dengan makhluk hidup lain. Sebagai contoh, seorang petugas pemadam kebakaran memberi minum koala yang terluka karena kebakaran hutan, menyelamatkan kucing pada saat terjadi banjir, penanaman mangrove di sepanjang pantai, dan pemasangan peraturan dilarang menebang pohon di hutan atau daerah konservasi.

\subsubsection{Pandangan Ekosentrisme}

Ekosentrisme memandang etika berlaku pada keseluruhan komponen lingkungan, seluruh komunitas ekologis, baik yang hidup maupun tidak. Secara ekologis, makhluk hidup dan benda-benda abiotis lainnya saling terkait satu sama lainnya. Karena itu, kewajiban dan tanggung jawab moral tidak hanya dibatasi pada makluk hidup tetapi juga pada lingkungan tak hidup. Etika ekosentrisme populer dengan istilah deep ecology yang diperkenalkan pertama kali oleh Arne Naess, seorang filsuf Norwegia pada tahun 1973.

Deep Ecology menuntut etika baru yang tidak hanya berpusat pada manusia, tetapi pada makluk hidup seluruhnya dalam kaitannya dengan upaya mengatasi persoalan lingkungan. Hal yang baru yaitu, pertama, manusia dan kepentingannya bukan lagi ukuran bagi segala sesuatu. Manusia bukan lagi pusat dunia moral. Kedua, bahwa etika lingkungan hidup yang dikembangkan deep ecology dirancang sebagai sebuah etika praktis, yaitu sebuah gerakan. Artinya prinsip moral etika lingkungan harus diterjemahkan dalam aksi nyata dan konkrit. Dengan demikian, deep ecology menuntut orang-orang untuk mempunyai sikap dan keyakinan yang sama, mendukung gaya hidup selaras dengan alam, dan sama-sama memperjuangkan isu lingkungan. Suatu gerakan yang menuntut perubahan cara pandang, nilai, dan perilaku (gaya hidup). Sebagai contoh, pelaksanaan reklamasi pada lahan pasca tambang, penangkaran kupu-kupu di Taman Nasional Bantimurung Bulusaraung Sulawei Selatan, dan pemasangan aturan dilarang membuang sampah sembarangan di sungai, laut, dan tempat-tempat lain.

\subsection{Konsep Khalîfah fì al-ard dalam Al-Qur'an}

Secara etimologis khaliffah merupakan bentuk kata dari khalifun artinya menggantikan yang berarti pihak yang tepat menggantikan posisi pihak yang memberi kepercayaan. Sedangkan secara terminologis, 
kata khalîfah mempunyai makna fungsional yang berarti mandataris (pengemban tanggung jawab) atau pihak yang diberikan tanggung jawab oleh pemberi mandat (Allah SWT). Kekhalîfahan adalah amanah, maka khaliffah merupakan pilar penting yang dapat membawa perbaikan bagi lingkungan. Manusia yang menerima tanggung jawab sebagai khaliffah haruslah bertanggung jawab terhadap kelangsungan kehidupan di bumi, sesuai dalam QS. al-Ahzâb [33]: 72:

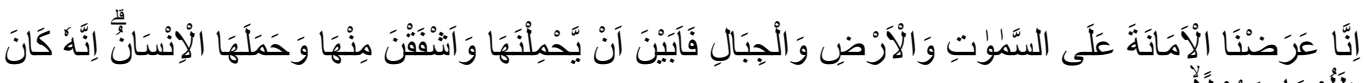

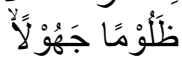

Sesungguhnya Kami telah mengemukakan amanat kepada langit, bumi dan gunung-gunung, maka semuanya enggan untuk memikul amanat itu dan mereka khawatir akan mengkhianatinya, dan dipikullah amanat itu oleh manusia. Sesungguhnya manusia itu amat zalim dan amat bodoh.

Fil ard artinya di bumi. Khalîfah fî al-ard berarti menggantikan Allah SWT dalam menegakkan kehendaknya dan menerapkan ketetapan-ketetapannya di muka bumi ini. Tetapi bukan berarti Allah tidak mampu, namun karena Allah hendak menguji manusia dan memberinya kehormatan.

Allah berfirman dalam QS. al-Baqarah [2]: 30:

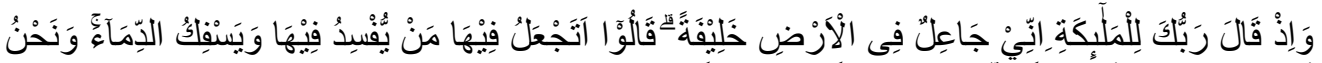

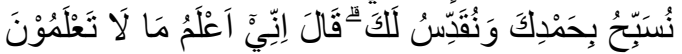

Dan (ingatlah) ketika Tuhanmu berfirman kepada para malaikat: "Sesungguhnya Aku hendak menjadikan di muka bumi itu seorang khaliffah." Mereka berkata: "Apakah Engkau hendak menjadikan (khaliffah) di bumi itu orang yang akan membuat kerusakan padanya dan menumpahkan darah, padahal kami senantiasa bertasbih dengan memuji Engkau dan mensucikan Engkau?" Tuhan berfirman: "Sesungguhnya Aku lebih mengetahui apa yang tidak kalian ketahui.

Selain itu, pada QS. Sad [38]: 26:

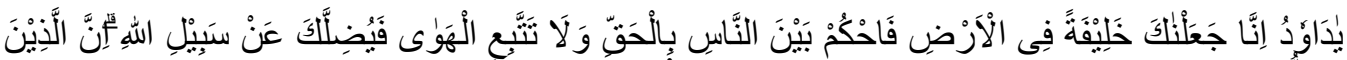

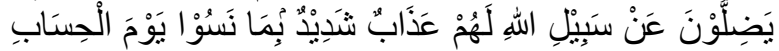

Hai Daud, sesungguhnya Kami menjadikan kamu khalîfah di muka bumi, maka berilah keputusan diantara manusia dengan adil dan janganlah kamu mengikuti hawa nafsu, karena ia akan menyesatkan kamu dari jalan Allah. Sesungguhnya orang-orang yang sesat dari jalan Allah akan mendapat azab yang berat, karena mereka melupakan hari perhitungan.

Sebagai khalîfah fì al-ard (wakil Allah di bumi), manusia wajib untuk merepresentasikan dirinya sesuai dengan sifat-sifat Allah. Salah satu sifat Allah adalah pemelihara atau penjaga alam, untuk itu manusia bertanggung jawab dalam menjaga atau memelihara bumi, yaitu menjaga keberlangsungan fungsi bumi sebagai tempat kehidupan semua makhluk ciptaan Allah. Dalam kedudukan inilah manusia bertanggung jawab atas seluruh alam semesta. Hal ini sesuai QS. al-Anbiyâ'’ [21]: 107:

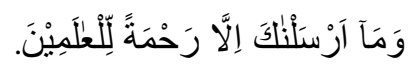

Dan tiadalah Kami mengutus kamu, melainkan untuk (menjadi) rahmat bagi semesta alam.

Manusia, hewan, dan tumbuhan sama-sama merupakan makhluk ciptaan Allah. Sebagai makhluk ciptaanNya, mereka senantiasa diwajibkan untuk beribadah kepada Allah. Sebagaimana disebutkan dalam QS. an-Nûr [24]: 41:

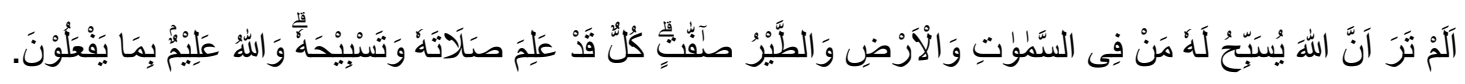


Tidaklah kamu tahu bahwasanya Allah: kepada-Nya bertasbih apa yang di langit dan di bumi dan (juga) burung dengan mengembangkan sayapnya. Masing-masing telah mengetahui (cara) sembahyang dan tasbihnya dan Allah Maha mengetahui apa yang mereka kerjakan.

Pada QS. al-Isrâ' [17]: 44 juga disebutkan:

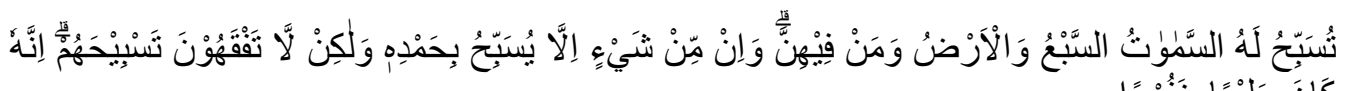

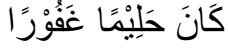

Langit yang tujuh, bumi, dan semua yang ada di dalamnya bertasbih kepada Allah. Dan tak ada sesuatupun melainkan bertasbih dengan memuji-Nya, tetapi kamu sekalian tidak mengerti tasbih mereka. Sesungguhnya Dia adalah Maha Penyantun lagi Maha Pengampun.

Akan tetapi, manusia diberi sedikit kelebihan dibanding makhluk lain yaitu akal pikiran. Kesadaran manusia dalam perannya sebagai khalîfah fî al-ard mempunyai arti bahwa dengan menggunakan akal pikiran, manusia dapat bertindak arif dan bijaksana dalam menjaga, mengelola, dan melestarikan segala yang ada di alam sehingga terhindar dari kerusakan. Pemberian akal pikiran juga merupakan ujian bagi manusia untuk tidak mengikuti hawa nafsunya (serakah) dalam memanfaatkan alam, sesuai pada QS. alAn'âm [6]: 165:

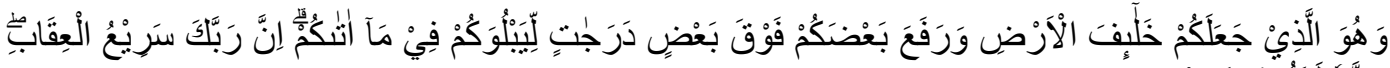

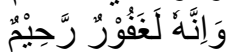

Dia meninggikan sebagian kamu atas sebagian (yang lain) beberapa derajat, untuk mengujimu tentang apa yang diberikan-Nya kepadamu. Sesungguhnya Tuhanmu Amat cepat siksaan-Nya dan Sesungguhnya Dia Maha Pengampun lagi Maha Penyayang.

Berdasarkan hasil kajian, konsep tentang khalîfah fî al-ard masih sangat terbatas. Belum ada buku

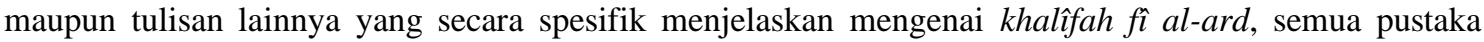
masih membahas secara umum yaitu tentang konservasi alam dalam Islam.

\subsection{Konsep Khalîfah fì al-ard dalam Perspektif Antroposentrisme}

Manusia sebagai khalîfah fî al-ard tidak berarti bahwa manusia adalah yang tertinggi dan berkuasa atas alam. Pemahaman manusia sebagai khalîfah mengimplikasikan bahwa manusia memiliki posisi sebagai wakil Allah yang diberi amanat untuk memelihara alam, bukan sebagai penguasa alam, karena penguasa alam semesta ini adalah Allah. Hal ini tentunya tidak memposisikan manusia sebagai pusat orientasi sebagaimana dalam pandangan antroposentrisme. Sehingga konsep khalîfah fî al-ard ini bertentangan dengan antroposentrisme.

Antroposentrisme memandang nilai tertinggi ada pada manusia sehingga manusia berhak melakukan apa saja atas alam. Hal ini mendorong manusia untuk melakukan eksploitasi besar-besaran terhadap alam, sehingga cara pandang antroposentrisme cenderung mengakibatkan terjadinya kerusakan alam. Sedangkan khalîfah fî al-ard sebaliknya, manusia mengemban tugas untuk memperbaiki dan memelihara alam. Tugas khalîfah fì al-ard sebagai pemelihara alam dijelaskan dalam QS. al-An'âm [6]: 102:

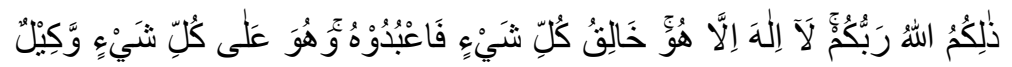

Yang memiliki sifat-sifat yang demikian itu ialah Allah Tuhan kamu; tidak ada Tuhan selain Dia; Pencipta segala sesuatu, maka sembahlah Dia; dan Dia adalah Pemelihara segala sesuatu. 
Dengan demikian, sebagai wakil Allah di muka bumi, sudah seharusnya manusia menjadi pemelihara bumi dari kerusakan. Konsep khalîfah fì al-ard tidak melarang manusia untuk memanfaatkan alam, namun hal tersebut harus dilaksanakan secara seimbang dan tidak berlebihan (mengikuti hawa nafsu) karena dapat menyebabkan kerusakan dan bencana. Kebanyakan manusia cenderung melihat kebenaran menurut hawa nafsu, kacamatanya, atau cara pandangnya sendiri. Ketika dia diingatkan, pastilah dia membantah dan mengatakan bahwa pendapatnya itu suatu kebaikan. Hal ini sesuai dengan QS. al-Mu'minûn [23]: 71:

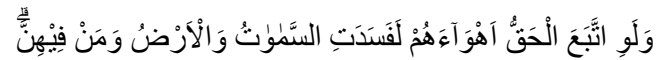
Kalau sekiranya kebenaran mengikuti hawa nafsu mereka niscaya binasalah langit dan bumi dan apa yang ada diantara keduanya.

Pertentangan konsep khalîfah fì al-ard dan antroposentrisme secara langsung disebutkan dalam QS. al-A'râf [7]: 56:

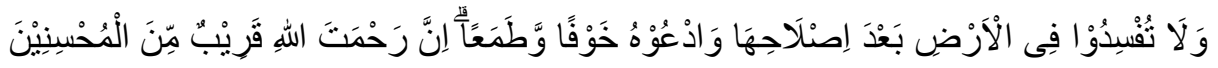

Dan janganlah kamu membuat kerusakan di muka bumi, sesudah (Allah) memperbaikinya dan berdoalah kepada-Nya dengan rasa takut (tidak akan diterima) dan harapan (akan dikabulkan). Sesungguhnya rahmat Allah amat dekat kepada orang-orang yang berbuat baik.

Selain itu, larangan untuk berbuat kerusakan juga disebutkan dalam QS. al-Baqarah [2]: 60 dan 195:

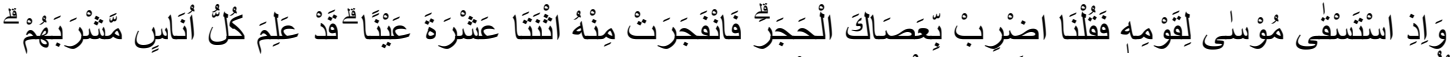

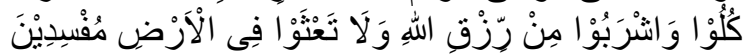

Dan (ingatlah) ketika Musa memohon air untuk kaumnya, lalu Kami berfirman: "Pukullah batu itu dengan tongkatmu". Lalu memancarlah daripadanya dua belas mata air. Sungguh tiap-tiap suku telah mengetahui tempat minumnya (masing-masing). Makan dan minumlah rezeki (yang diberikan) Allah, dan janganlah kamu berkeliaran di muka bumi dengan berbuat kerusakan.

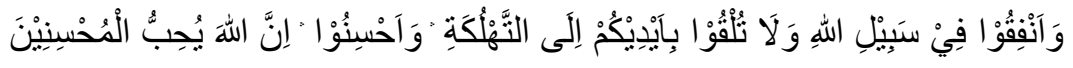

Dan belanjakanlah (harta bendamu) di jalan Allah, dan janganlah kamu menjatuhkan dirimu sendiri ke dalam kebinasaan, dan berbuat baiklah, karena sesungguhnya Allah menyukai orangorang yang berbuat baik.

Mengenai perbuatan manusia yang berbuat kerusakan di muka bumi telah disebutkan dalam QS. arRûm [30]: 41-42:

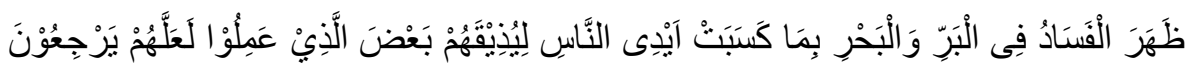

Telah nampak kerusakan di darat dan di laut disebabkan karena perbuatan tangan manusia, supaya Allah merasakan kepada mereka sebahagian dari (akibat) perbuatan mereka, agar mereka kembali (ke jalan yang benar).

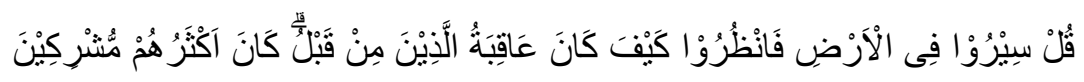

Katakanlah: "adakanlah perjalanan di muka bumi dan perhatikanlah bagaimana kesudahan orangorang dahulu, kebanyakan dari mereka adalah orang-orang yang mempersekutukan (Allah)”.

Akibat dari perbuatan manusia yang berlebih-lebihan dalam memanfaatkan bumi disebutkan pada QS. ar-Rûm [30]: 9:

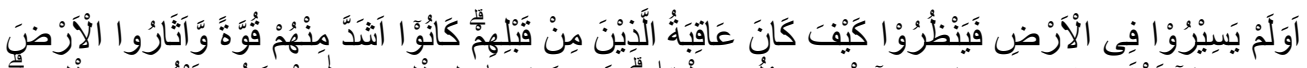

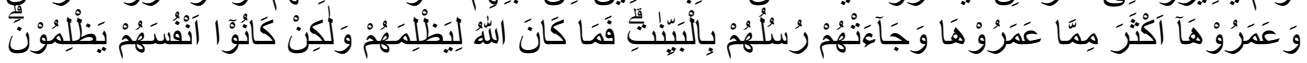


Dan apakah mereka tidak mengadakan perjalanan di muka bumi dan memerhatikan bagaimana akibat (yang diderita) oleh orang-orang sebelum mereka? Orang-orang itu adalah lebih kuat dari mereka dan telah mengolah bumi (tanah) serta memakmurkannya lebih banyak dari apa yang telah mereka makmurkan. Dan telah datang kepada mereka Rasul-rasul mereka dengan membawa buktibukti yang nyata. Maka Allah sekali-kali tidak berlaku zalim kepada mereka, akan tetapi merekalah yang berlaku zalim kepada diri sendiri.

Ayat-ayat tersebut menunjukkan bahwa kerusakan lingkungan pada akhirnya akan menyebabkan kebinasaan bagi manusia sendiri. Sebagai contoh, perilaku manusia yang merusak hutan berakibat pada bencana banjir yang mengkibatkan hilangnya nyawa dan harta benda manusia. Industri-industri besar dengan segala pencemarnya yang dibuang ke udara, sungai, dan laut. Pertambangan dan pengeboran minyak yang berakibat kerusakan dan pencemaran lingkungan. Pemanasan global juga terjadi akibat ulah manusia. Kesemuanya itu telah memakan korban jiwa tidak hanya manusia tetapi juga makhluk hidup lain (hewan dan tumbuhan).

Ketika bencana alam datang, manusia seharusnya menyadari kesalahannya. Allah telah menciptakan alam semesta dengan seimbang, tetapi karena manusia berbuat sewenang-wenang, tidak taat hukum, dan mementingkan diri sendiri, maka alam menumpahkan amarah dengan berbagai bencana. Berlebih-lebihan dalam menguras sumberdaya alam merupakan penyebab utama terjadinya bencana. Pemulihan kondisi bumi yang telah rusak memerlukan waktu sangat lama. Manusia sebagai khalîfah fí al-ard mempunyai amanat dalam menjaga kelestarian lingkungan. Amanat sudah semestinya dijaga. Akan tetapi, manusia merusak dirinya dengan kemaksiatan. Manusia merusak bumi dan segala isinya setelah sekian banyak nikmat telah Allah berikan untuknya.

Hubungan konsep khalîfah fì al-ard dan antroposentrisme ditampilkan pada Gambar 1.

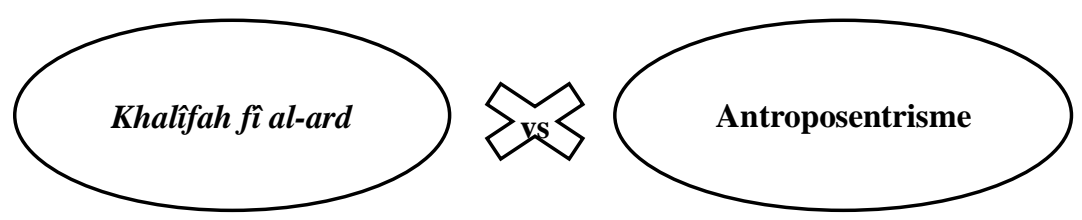

Gambar 1. Hubungan Konsep Khalîfah fi al-ard dan Antroposentrisme

\subsection{Konsep Khalîfah fì al-ard dalam Perspektif Biosentrisme}

Konsep yang ada dalam biosentrisme merupakan bagian dari konsep khalîfah fí al-ard. Biosentrisme berpandangan bahwa setiap kehidupan dan makhluk hidup dalam hal ini tumbuhan dan hewan mempunyai nilai dan berharga pada dirinya sendiri. Hal ini sesuai dengan konsep khalîfah fî al-ard yang menyatakan bahwa manusia bertanggungjawab atas seluruh alam semesta, karena tumbuhan dan hewan merupakan bagian dari alam semesta.

Berkaitan dengan kehidupan makhluk hidup lain (tumbuhan), manusia mempunyai hak (diperbolehkan) untuk memanfaatkannya dengan syarat tidak melampaui batas atau berlebihan. Hal ini dijelaskan dalam QS. al-An'âm [6]: 141:

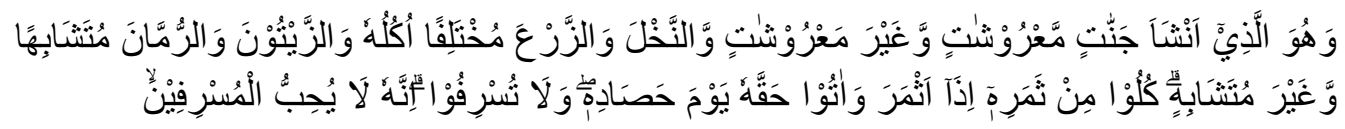

Dan dialah yang menjadikan kebun-kebun yang berjunjung dan yang tidak berjunjung, pohon kurma, tanam-tanaman yang bermacam-macam buahnya, zaitun dan delima yang serupa (bentuk dan warnanya) dan tidak sama (rasanya). Makanlah dari buahnya (yang bermacam-macam itu) bila dia berbuah, dan tunaikanlah haknya di hari memetik hasilnya (dengan disedekahkan kepada fakir miskin); dan janganlah kamu berlebih-lebihan. Sesungguhnya Allah tidak menyukai orang yang berlebih-lebihan. 
Ayat tersebut mengandung arti bahwa seorang khalîfah fî al-ard tidak boleh berlebihan dalam memanfaatkan alam (tumbuhan). Dapat diartikan misalnya, hanya mengambil buah jika telah masak, tidak mengambil yang belum masak, membiarkan yang masih berbunga (tidak merusaknya) sehingga kehidupan pohon tersebut terus berlangsung.

Konsep khalîfah fî al-ard yang berkaitan dengan sikap terhadap hewan dicontohkan oleh kisah Nabi Sulaiman yang menyuruh pasukannya berhenti dan mempersilahkan semut-semut lewat agar tidak terinjak, ini terdapat dalam QS. an-Naml [27]: 18-19:

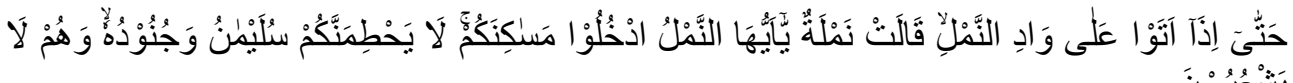

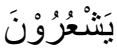

Hingga ketika mereka sampai di lembah semut, berkatalah seekor semut, "Wahai semut-semut! Masuklah ke dalam sarang-sarangmu, agar kamu tidak diinjak oleh Sulaiman dan bala tentaranya, sedangkan mereka tidak menyadari”.

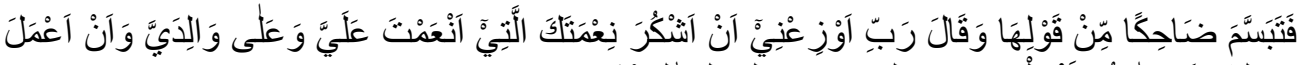

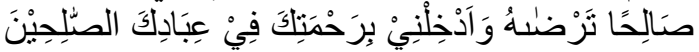

Maka dia (Sulaiman) tersenyum lalu tertawa karena (mendengar) perkataan semut itu. Dan dia berdoa, "Ya Tuhanku, anugerahkanlah aku ilham untuk tetap mensyukuri nikmat-Mu yang telah Engkau anugerahkan kepadaku dan kepada kedua orang tuaku dan agar aku mengerjakan kebajikan yang Engkau ridhai, dan masukkanlah aku dengan rahmat-Mu ke dalam golongan hamba-hamba-Mu yang sholeh."

Selain itu, juga disebutkan pada QS. al-An’âm [6]: 38:

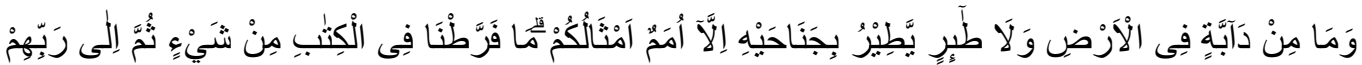

$$
\begin{aligned}
& \text { بُحْشْرَرْْنَ }
\end{aligned}
$$

Dan tiadalah binatang-binatang yang ada di bumi dan burung-burung yang terbang dengan kedua sayapnya, melainkan umat juga seperti kamu. Tiadalah Kami alpakan sesuatupun dalam Al Kitab, kemudian kepada Tuhanlah mereka dihimpunkan.

Pada QS. al-Baqarah [2]: 205 juga disebutkan:

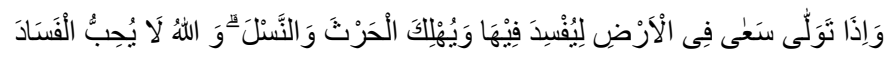

Dan apabila ia berpaling (dari kamu), ia berjalan di bumi untuk mengadakan kerusakan padanya, dan merusak tanam-tanaman dan binatang ternak, dan Allah tidak menyukai kebinasaan.

Berdasarkan ayat-ayat tersebut, bahwa seorang khalîfah fî al-ard harus berbuat baik terhadap makhluk hidup lain (hewan dan tumbuhan), karena selain mereka mempunyai nilai (value), mereka juga bagian dari umatNya (makhluk ciptaan Allah), sama seperti manusia.

Catatan sejarah Islam menyebutkan bahwa sesaat setelah Amr bin Ash menaklukkan Mesir, seekor burung merpati membuat sarang di atas tendanya. Padahal mereka segera akan berangkat meninggalkan Mesir. Sebenarnya Amr bin Ash dapat memerintahkan para prajuritnya untuk membongkar tendanya. Namun, dia tidak melakukannya sebab tidak ingin mengusik merpati yang sedang mengerami telurnya. Tenda itupun dia tinggalkan. Catatan tersebut merupakan salah satu contoh dari tindakan manusia sebagai khalîfah fî al-ard.

Sebagai khalîfah fî al-ard, manusia harus menjaga, melestarikan, tidak menyakiti, atau merusak kehidupan makhluk hidup lain yang merupakan bagian alam semesta. Manusia memang lebih unggul dibanding makhluk lain. Namun, tanpa makhluk lain, kehidupan manusia tidak ada artinya. Tidak dapat dibayangkan apabila di muka bumi ini tidak terdapat tumbuhan dan hewan. Pada kenyataannya, zaman ilmu pengetahuan dan teknologi tidak sepenuhnya menjamin keselamatan dan kesejahteraan manusia. 
Sebaliknya, manusia terancam oleh kepandaian, kerakusan, dan kesombongannya, sehingga kehidupan manusia makin cepat dalam kebinasaan. Semua ini dikarenakan manusia hanya menggunakan hawa nafsunya dan tidak mengambil pelajaran dari firman-firman Allah.

Hubungan konsep khalîfah fì al-ard dan biosentrisme ditampilkan pada Gambar 2.

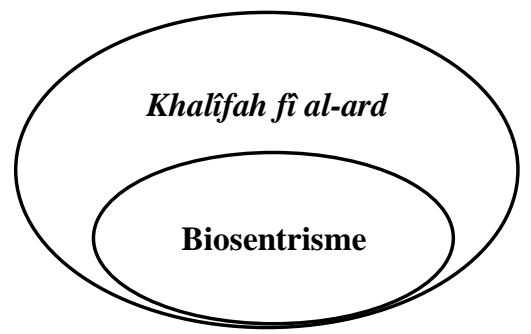

Gambar 2. Hubungan Konsep Khaliffah fí al-ard dan Biosentrisme

\subsection{Konsep Khalîfah fĩ al-ard dalam Perspektif Ekosentrisme}

Konsep khalîfah fî al-ard sangat sesuai dengan ekosentrisme, sehingga dapat dikatakan bahwa konsep khalîfah fi al-ard sama dengan ekosentrisme. Sebagai khalifah, manusia memiliki kewajiban melestarikan alam dengan sebaik-baiknya agar kehidupan di dunia berlangsung sejahtera. Konsep ekosentrisme yang menuntut etika baru yang tidak hanya berpusat pada manusia, tetapi berpusat pada makluk hidup seluruhnya dalam kaitannya dengan upaya mengatasi persoalan lingkungan hidup sesuai dengan tugas khalîfah fì al-ard yang salah satu tugasnya yaitu tidak berbuat kerusakan di muka bumi. Khalîfah fî al-ard dan ekosentrisme sama-sama menuntut manusia untuk hidup selaras dengan alam.

Kesesuaian konsep khalîfah fì al-ard dan ekosentrisme yang sama-sama mendorong untuk pemeliharaan lingkungan dan menentang perbuatan kerusakan dinyatakan dalam QS. al-Baqarah [2]: 1112:

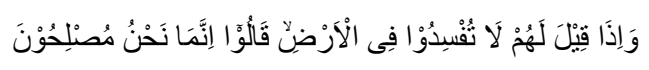

Dan apabila dikatakan kepada mereka: Janganlah kamu membuat kerusakan di muka bumi, mereka menjawab: Sesungguhnya kami orang-orang yang mengadakan perbaikan. Ingatlah, sesungguhnya mereka itulah orang-orang yang membuat kerusakan, tetapi mereka tidak sadar.

Pada QS. al-A'râf [7]: 74 juga disebutkan:

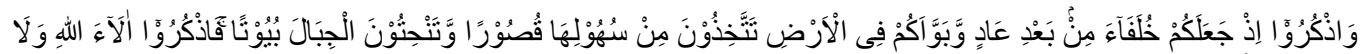

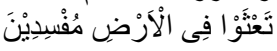

Dan ingatlah olehmu di waktu Tuhan menjadikan kamu pengganti-pengganti (yang berkuasa) sesudah kaum Aad dan memberikan tempat bagimu di bumi. Kamu dirikan istana-istana di tanahtanahnya yang datar dan kamu pahat gunung-gunungnya untuk dijadikan rumah; maka ingatlah nikmat-nikmat Allah dan janganlah kamu merajalela di muka bumi membuat kerusakan.

Selain itu, dalam QS. al-Qasas [28]: 77 juga disebutkan:

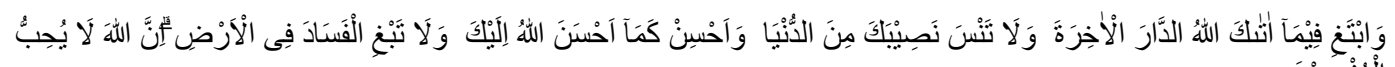

Dan carilah pada apa yang telah dianugerahkan Allah kepadamu (kebahagiaan) negeri akhirat, dan janganlah kamu melupakan bagianmu dari (kenikmatan) duniawi dan berbuat baiklah sebagaimana Allah telah berbuat baik kepadamu dan janganlah kamu berbuat kerusakan di muka bumi. Sesungguhnya Allah tidak menyukai orang-orang yang berbuat kerusakan.

Larangan berbuat kerusakan disebutkan pada QS. ash-Shu'arâ' [26]: 151-152: 
Dan janganlah kamu menaati perintah orang-orang yang melewati batas

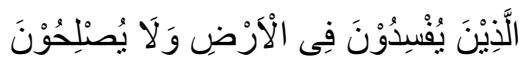

Yang membuat kerusakan di muka bumi dan tidak mengadakan perbaikan.

Alam semesta diciptakan tidak dalam keadaan sia-sia. Segala unsur lingkungan baik hidup (biotik) maupun tak hidup (abiotik) membentuk satu kesatuan hubungan saling tergantung sebagai tatanan ekosistem yang menyeluruh dan manusia juga termasuk bagian di dalamnya. Adanya gangguan pada salah satu unsur, akan menyebabkan terganggunya keseimbangan ekosistem. Sesuai dengan QS. Âli 'Imrân [3]: 191:

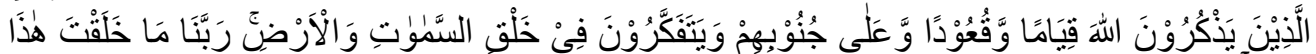

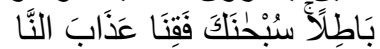

(yaitu) orang-orang yang mengingat Allah sambil berdiri atau duduk atau dalam keadaan berbaring dan mereka memikirkan tentang penciptaan langit dan bumi (seraya berkata): "Ya Tuhan kami, tiadalah Engkau menciptakan ini dengan sia-sia, Maha Suci Engkau, maka peliharalah kami dari siksa neraka."

Selain itu, dalam QS. ad-Dukhân [44]: 38-39 disebutkan bahwa:

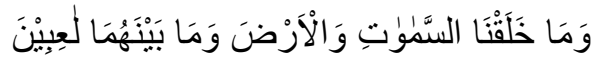

Dan kami tidak menciptakan langit dan bumi dan apa yang ada diantara keduanya dengan bermain-main.

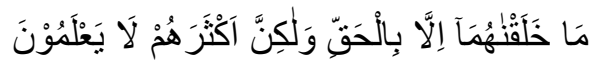

Kami tidak menciptakan keduanya melainkan dengan haq, tetapi kebanyakan mereka tidak mengetahui.

Ayat-ayat tersebut menyatakan bahwa segala sesuatu di alam mempunyai nilai sendiri karena mereka diciptakan dengan tidak sia-sia. Oleh karena itu, manusia dituntut untuk bersikap dan bertanggung jawab terhadap lingkungannya (environmentally responsible life style), harus menjaga dan memelihara kelestarian lingkungan. Manusia diperintahkan berbuat maslahat atau kebaikan di muka bumi serta menghindari segala perbuatan yang dapat merugikan dan merusak. Dengan membuat rusak alam ini, maka pada dasarnya telah membuat sakit Allah sebagai creator alam. Hal ini disebutkan dalam QS. anNahl [16]: 90:

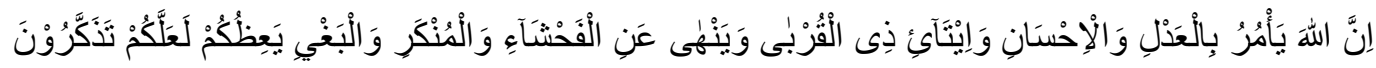

Sesungguhnya Allah menyuruh kamu berlaku adil dan berbuat kebajikan, memberi kepada kaum kerabat, dan Allah melarang dari berbuat keji, kemungkaran, dan permusuhan. Dia memberi pengajaran kepadamu agar kamu dapat mengambil pelajaran.

Pada zaman Rasulullah saw, telah dikenal praktek konsep pelestarian alam, yaitu Hima' dan Ihya'ul Mawat. Hima' atau kawasan hutan lindung adalah kawasan yang khusus dilindungi pemerintah atas dasar syariat guna melestarikan kehidupan liar dan hutan. Rasulullah saw pernah menyegarkan kawasan sekitar Madinah sebagai hima' guna melindungi lembah, padang rumput, dan tumbuhan yang ada di dalamnya. Sementara konsep Ihya'ul Mawat adalah usaha mengelola lahan yang masih belum bermanfaat menjadi berguna bagi manusia (Mangunjaya, 2005).

Hubungan konsep khalîfah fì al-ard dan ekosentrisme dapat ditampilkan pada Gambar 3. 


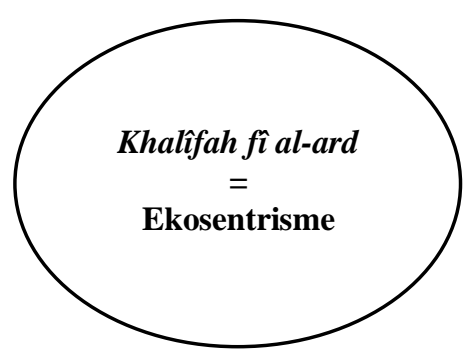

Gambar 3. Hubungan Konsep Khalîfah fí al-ard dan Ekosentrisme

\subsection{Prinsip-prinsip Khalîfah fì al-ard dan Etika Lingkungan}

Berdasarkan uraian di atas, dapat disarikan bahwa khalîfah fí al-ard memiliki empat prinsip, yaitu: selalu tunduk dan patuh kepada Allah, tidak berbuat kerusakan di bumi, memakmurkan bumi (memelihara dan memperbaiki), dan mengendalikan hawa nafsu (tidak berlebih-lebihan). Sedangkan pada etika lingkungan, terdapat sembilan prinsip, yaitu: sikap hormat terhadap alam, tanggung jawab, solidaritas kosmis, kasih sayang dan kepedulian terhadap alam, No harm, hidup sederhana dan selaras dengan alam, keadilan, demokrasi, dan integritas moral.

Prinsip-prinsip yang ada dalam khalîfah fì al-ard maupun etika lingkungan memiliki tujuan yang sama, yaitu terciptanya keseimbangan alam semesta yang didalamnya mencakup seluruh ekosistem baik hidup (hewan, tumbuhan, manusia) maupun tak hidup (tanah, air, udara, batuan) karena semuanya saling terkait satu sama lain agar keberlangsungannya tetap terjaga dan lestari.

\subsection{Pelaksanaan Konsep Khalîfah fì al-ard}

Pelaksanaan konsep khalîfah fî al-ard dapat dipakai dalam dua level, yaitu pada level individu dan kolektif. Pada level individu, pelaksanaan khalîfah fì al-ard dimulai dari diri sendiri. Misalnya dengan membiasakan sikap dan perilaku ramah lingkungan (menyayangi hewan, melakukan gerakan hemat air, tidak membuang sampah sembarangan, hemat listrik, memanfaatkan kembali barang-barang bekas terutama plastik dan kertas, dan lain-lain).

Pada level kolektif, pelaksanaan khalîfah fĩ al-ard dimulai dari lingkungan keluarga, karena keluarga merupakan unit sosial terkecil dalam kehidupan masyarakat. Misalnya dengan menghijaukan pekarangan rumah dengan tanaman obat-obatan (apotik hidup), tanaman hias, dan pohon; mengelola sampah dengan memisahkan sampah organik dan anorganik; membuat sumur resapan; dan lain-lain. Setelah lingkungan keluarga, pelaksanaan khalîfah fì al-ard dilakukan pada lingkungan masyarakat (sekolah, tempat kerja, desa, kecamatan, kabupaten, provinsi, nasional, dan bahkan dunia). Dimanapun berada, seluruh umat manusia yang sejatinya merupakan khaliffah fì al-ard harus menjaga dan memelihara alam, misalnya dengan tidak menebang pohon sembarangan (kalau menebang harus diganti dengan pohon yang baru); tidak membuang sampah dan limbah dari industri, rumah sakit, hotel, dan sebagainya ke sungai dan laut; tidak berburu hewan langka; melindungi dan memelihara keanekaragaman dan kelestarian hutan, pesisir, dan gunung; memberlakukan hukuman bagi pelaku perusakan dan pencemaran lingkungan; dan lain-lain.

Manusia sebagai seorang khalîfah fì al-ard baik pada level individu maupun level kolektif dimanapun berada harus tetap konsisten menunjukkan sikap dan perilaku yang baik dan bertanggung jawab dalam mengelola dan melestarikan alam yang ada di sekitarnya serta menjaganya dari kerusakan dan pencemaran.

\section{Simpulan}

Konsep khalîfah fì al-ard dapat dijadikan sebagai solusi untuk menggeser cara pandang antroposentrisme yang sudah mendarah daging pada sebagian besar manusia di bumi. Konsep khalîfah fi al-ard yang dimaknai sebagai wakil Allah di muka bumi seharusnya menjadi titik awal manusia dalam 
mengelola dan memelihara lingkungan, sehingga konsep ini merupakan salah satu sarana strategis dalam penataan dan pemeliharaan lingkungan.

Konsep khalîfah fi al-ard sangat relevan dengan etika lingkungan (biosentrisme dan ekosentrisme). Hal ini didukung oleh ayat-ayat dalam al-Qur'an. Sehingga konsep khalîfah fì al-ard ini merupakan pedoman yang sesuai untuk pengelolaan lingkungan dalam rangka mengatasi berbagai masalah lingkungan. Pelaksanaan konsep khalîfah fî al-ard dapat dipakai baik pada level individu maupun kolektif. Konsep khalîfah fî al-ard dapat diwujudkan menjadi sebuah gerakan pro-lingkungan seperti lembagalembaga pecinta lingkungan lainnya, karena pada dasarnya mempunyai prinsip dan tujuan yang sama.

Tantangan dari pelaksanaan konsep khalîfah fì al-ard yaitu masih banyaknya manusia yang berpandangan antroposentrisme (kehidupan yang materialistis dan hedonis) yang tidak jarang memperoleh dukungan dan kekuatan dari pemerintah atau negara. Selain itu, diperlukan cara untuk membangun kesadaran manusia akan peran dirinya sebagai pemelihara alam. Konsep tentang khalîfah fî al-ard sangat penting untuk dipelajari lebih lanjut terutama bagi kita sebagai umat Islam untuk mengerti makna esensial diri kita sebagai khalîfah fî al-ard..

\section{Ucapan terimakasih}

Ucapan terima kasih disampaikan kepada penyelenggara Program Beasiswa Unggulan, Biro Perencanaan dan Kerjasama Luar Negeri, Sekretariat Jenderal, Kementrian Pendidikan dan Kebudayaan TA 2015/2016 yang telah memberikan beasiswa biaya pendidikan untuk penulis dalam menempuh studi jenjang S3.

\section{Daftar Pustaka}

Departemen Agama RI. (2002). Al-Qur'an dan Terjemahannya. Jakarta: Darus Sunnah.

Hadi, S. (1995). Metodologi Research Jilid IV. Yogyakarta: Andi Offset.

Keraf, A. S. (2010). Etika Lingkungan Hidup. Jakarta: Kompas.

Mangunjaya, F.M. (2005). Konservasi Alam dalam Islam. Jakarta: Yayasan Obor Indonesia.

MNLH. (2009). Undang-undang Nomor 32 Tahun 2009 tentang Perlindungan dan Pengelolaan Lingkungan Hidup. Jakarta-Indonesia: Menteri Negara Lingkungan Hidup.

Nazir, M. (1988). Metode Penelitian. Jakarta: Ghalia Indonesia.

Soemiarno, S., Kartono, H., dan Purbaningsih, S. (2010). Buku Ajar III: Bangsa, Budaya, dan Lingkungan Hidup di Indonesia. Jakarta: Badan Penerbit FK UI.

Tim MKU PLH. (2014). Buku Ajar MKU: Pendidikan Lingkungan Hidup. Semarang: Universitas Negeri Semarang. 